\title{
MALTHUSIAN OVERFISHING AND EFFORTS TO OVERCOME IT ON KENYAN CORAL REEFS
}

\author{
Tim R. McClanahan, ${ }^{1,4}$ Christina C. Hicks, ${ }^{2,5}$ and Emily S. Darling ${ }^{3}$ \\ ${ }^{1}$ Wildlife Conservation Society, Marine Programs, Bronx, New York 10460 USA \\ ${ }^{2}$ Coral Reef Conservation Project, P.O. Box 99470, Mombasa, Kenya \\ ${ }^{3}$ Simon Fraser University, Burnaby, British Columbia V5A 1S6 Canada
}

\begin{abstract}
This study examined trends along a gradient of fishing intensity in an artisanal coral reef fishery over a 10 -year period along $75 \mathrm{~km}$ of Kenya's most populated coastline. As predicted by Malthusian scenarios, catch per unit effort (CPUE), mean trophic level, the functional diversity of fished taxa, and the diversity of gear declined, while total annual catch and catch variability increased along the fishing pressure gradient. The fishery was able to sustain high $\left(\sim 16 \mathrm{Mg} \cdot \mathrm{km}^{-2} \cdot \mathrm{yr}^{-1}\right)$ but variable yields at high fishing pressure due to the dominance of a few productive herbivorous fish species in the catch. The effect of two separate management strategies to overcome this Malthusian pattern was investigated: fisheries area closure and elimination of the dominant and most "competitive" gear. We found that sites within $5 \mathrm{~km}$ of the enforced closure showed significantly lower total catch and CPUE, but increased yield stability and trophic level of catch than predicted by regression models normalized for fishing effort. Sites that had excluded illegal beach seine use through active gear management exhibited increased total catch and CPUE. There was a strong interaction between closure and gear management, which indicates that, for closures to be effective at increasing catch, there must be simultaneous efforts at gear management around the periphery of the closures. We propose that Malthusian effects are responsible for the variation in gear and catch and that active management through reduced effort and reductions in the most competitive gear have the greatest potential to increase the functional and trophic diversity and per-person productivity.
\end{abstract}

Key words: artisanal fisheries; demographic change; gear use and management; fisheries closures; fisheries yields; Kenya; marine protected areas; resource competition; social-ecological systems.

\section{INTRODUCTION}

Coral reef ecosystems are among the ocean's most diverse ecosystems, and they have moderate fisheries production potential that provides a resource for millions of tropical people (Nixon 1982, McManus 1996, Newton et al. 2007). Despite their ecological and economic importance, much remains to be understood about the full consequences of fishing and the sustainable management of this resource (Polunin and Roberts 1996). Yields from coral reef fisheries are quite variable, ranging from 0.1 to $50 \mathrm{Mg} \cdot \mathrm{km}^{-2} \cdot \mathrm{yr}^{-1}(1 \mathrm{Mg}=1$ metric ton; McClanahan 2006), and are expected to be influenced by many social and ecological factors that characterize complex multispecies fisheries (Matsuda and Abrams 2006). Fishing effort, gear use, time and space closures, the sizes of caught fish, their taxonomic composition of the catch, and their feeding habits are all expected to influence reef fisheries yields (McClanahan

Manuscript received 29 May 2007; revised 20 December 2007; accepted 15 February 2008. Corresponding Editor: K. Stokesbury.

${ }^{4}$ E-mail: tmcclanahan@wcs.org

${ }^{5}$ Present address: School of Marine Science and Technology, Newcastle University, Newcastle upon Tyne, United Kingdom.
2006). Investigations that determine how these factors can influence catch are needed for management tools to alleviate the growing global fisheries crises (McGoodwin 1990, Worm et al. 2006, Newton et al. 2007).

Similar to many ecosystems, coral reefs are under pressure from high human populations in tropical countries, which has the potential to undermine their productivity, biodiversity, and sustainability and lead to desperate resource users and destructive fishing methods (Pauly et al. 1989, McManus et al. 2000, McClanahan and Mangi 2004). Support for a Malthusian view of fishing (where fishing effort and competitive/destructive gear increase in proportion to human population growth and declining resources) is supported by case studies in countries with high human population growth rates and capitalization or globalization of the fishery (McManus 1997, Pauly et al. 2001, McClanahan et al. 2005, Cinner and McClanahan 2006). There is, however, the potential for human social organization and the creation of economic alternatives that can potentially overcome social-ecological tragedies (Dietz et al. 2003, Berkes and Seixas 2005, Turner et al. 2007). The extent to which these are truly holistic solutions or just temporary fixes of minor consequence to the larger Malthusian globalization dilemma remains an area of investigation requiring close scrutiny (Armitage and Johnson 2006). 


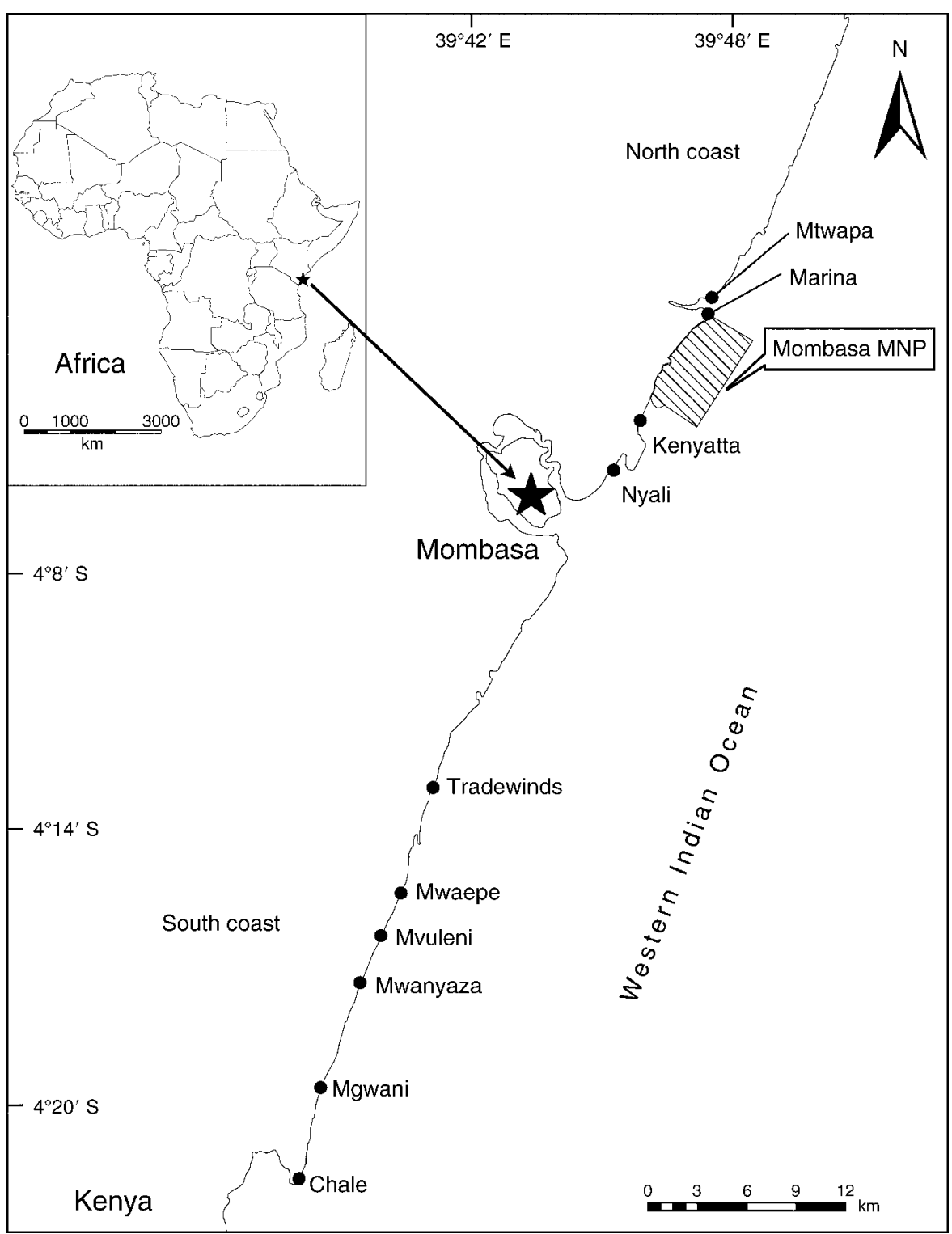

FIG. 1. Map of the southern Kenya coastline with locations of the Mombasa Marine National Park (MNP) and the 10 fishery landing sites used in this study.

We provide results of a 10-year study of fishery yields in the mature fishery of southern Kenya where numbers of fishers were increasing at $\sim 2 \%$ per year, similar to human population density (McClanahan et al. 2002). The history, social context, and some preliminary findings of these management changes have previously been described (McClanahan et al. 2005, McClanahan 2007). Here, we focus on the large-scale picture of the fishery in the context of total fishing effort and gear use where 10 landing sites were studied across a 10-year period of a changing management environment. We use an existing gradient of fishing pressure along the southern coast of Kenya to test predictions of Malthusian overexploitation and the effectiveness of resource- use measures and social organization to overcome problems around this fishery. We test the hypothesis that catch productivity and stability, functional diversity, trophic level, and gear diversity decline as fishing pressure increases. We also examine the effects of two common management methods, area closures and reduced use of a competitive or destructive fishing gear, on predicted Malthusian associations.

\section{Methods}

Study sites and gear use

We studied 10 major fishing landing sites over 10 years along an $\sim 75-\mathrm{km}$ stretch of coastline in southern Kenya (Fig. 1). All sites were representative of the multi- 
TABLE 1. Description of the 10 studied landing sites including number of sampling days, fishing effort (mean \pm SE) and area, proximity to a marine protected area, and history of beach seine management in Kenya.

\begin{tabular}{llccccc}
\hline \hline $\begin{array}{c}\text { Landing } \\
\text { site }\end{array}$ & $\begin{array}{c}\text { Management } \\
\text { group }\end{array}$ & $\begin{array}{c}\text { Sampling } \\
\text { days }(N)\end{array}$ & $\begin{array}{c}\text { Fishing effort } \\
\left(\text { no. fishers } \mathrm{km}^{-2} \cdot \mathrm{d}^{-1}\right)\end{array}$ & $\begin{array}{c}\text { Fishing } \\
\text { area }\left(\mathrm{km}^{2}\right)\end{array}$ & $\begin{array}{c}\text { Protected area } \\
<5 \mathrm{~km} \text { to site }\end{array}$ & $\begin{array}{c}\text { Year of beach } \\
\text { seine exclusion }\end{array}$ \\
\hline Mtwapa & North coast & 100 & $7.15 \pm 0.14$ & 2.79 & Mombasa MNP & no exclusion \\
Marina & North coast & 151 & $21.8 \pm 0.37$ & 2.79 & Mombasa MNP & no exclusion \\
Nyali & North coast & 161 & $21.3 \pm 0.31$ & 2.18 & Mombasa MNP & no exclusion \\
Kenyatta & Kenyatta & 1155 & $7.76 \pm 0.05$ & 3.60 & Mombasa MNP & $1998-2002 \dagger$ \\
Chale & South coast & 260 & $21.5 \pm 0.20$ & 2.20 & none & 2001 \\
Mgwani & South coast & 245 & $15.1 \pm 0.19$ & 2.20 & none & 1999 \\
Mwaepe & South coast & 284 & $11.3 \pm 0.15$ & 2.63 & none & 1997 \\
Mwanyaza & South coast & 258 & $13.9 \pm 0.14$ & 2.31 & none & $>20$ years ago \\
Mvuleni & South coast & 262 & $10.7 \pm 0.13$ & 2.31 & none & $>20$ years ago \\
Tradewinds & South coast & 314 & $4.81 \pm 0.07$ & 4.21 & none & 2005 \\
\hline
\end{tabular}

Note: "MNP" indicates Marine National Park.

$\dagger$ Kenyatta net modification transitional period.

gear, multispecies artisanal coral reef fishery in Kenya. Study sites were also selected because they were among the sites most commonly used by fishers and because they represented a range of human population density, gear use, and management strategies. At all sites, fishing is typically conducted from the shore to the outer reef in sand, coral, and seagrass habitats of the fringing reef lagoon (McClanahan and Mangi 2000). The Mombasa Marine National Park (Mombasa MNP) is located just north of the Kenyatta beach landing site and is surrounded by a fishing reserve that extends $\sim 1 \mathrm{~km}$ to the north and $\sim 12 \mathrm{~km}$ south of the park (Fig. 1). In Kenya, national parks are closed to resource extraction whereas fishing reserves are gear-restricted areas. The Kenya Wildlife Service (KWS) has successfully enforced this no-take fishery closure since 1991 (McClanahan et al. 2007). Kenyatta beach and the three North coast landing sites (Nyali, Marina, and Mtwapa) all lie within $5 \mathrm{~km}$ of the Mombasa reserve where gear restrictions apply but are variably enforced.

Artisanal fishers in Kenya use several types of fishing gear, which for the purpose of this study have been grouped into the main categories of hand line, spear gun, trap, beach seine, gill net, and "Kenyatta net." Gill net is the most common type of passive net in use, though other rare nets such as cast net and scoop net have been pooled under the net classification. The most common active net used in Kenya is the beach seine (pulled seine nets). Beach seines have a mesh size of 2-3 $\mathrm{cm}$ and are actively pulled through the entire water column by teams of 10-30 fishers. The use of this gear in the reserves has unsuccessfully been discouraged by KWS for some time and has also been illegal in Kenya since a government gazettement in 2001, but it is still commonly used (McClanahan et al. 2005). One focus of this study was to quantify the effects of efforts to reduce or remove beach seine nets. "Kenyatta net" was given a unique classification in this study because it was a pulled seine net that was reluctantly modified by fishers to satisfy the park service's efforts to eliminate beach seine use and was introduced into the northern section of the reserve adjacent to the southern end of the Mombasa
MNP. The process of change occurred over time and seine nets were originally entirely removed in 1994, reintroduced by fishers between 1998 and 2002. During this time of conflict, the nets were modified through repeated negotiations between park personnel and fishers, such that the high-intensity, small-mesh net was effectively removed from this landing site in 2002 but had undergone a transformation over the 1998-2002 period (McClanahan 2007). The net's length was reduced from between 400 and $600 \mathrm{~m}$ to $100-150 \mathrm{~m}$, the mesh size increased from $1 \mathrm{~cm}$ to $5-10 \mathrm{~cm}$, and was dragged by $2-6$ people (rather than $10-30$ ) over smaller areas. There was also an effort to exclude its use close to the park boundary after 2002. While beach seines were not encouraged in some landings sites in South coast for over 20 years (McClanahan et al. 1997), their removal spread to Mwaepe in 1997, Mgwani in 1999, and Chale in 2001; however, they were not completely eliminated in the full area until January 2005 (Table 1; McClanahan 2007). Beach seines were still currently the primary gear used in the North coast sites following difficulties in gear-restriction implementation (McClanahan et al. 2005).

\section{Sampling design and landing site sampling}

The study was designed to test for the effects of effort, fisheries closures, gear restrictions, and their interactions on the catch at these landing sites during a 10-year period between January 1996 and December 2005. The recovery of fish biomass inside parks requires more than five years and because the closures were established in 1991, this 10-year period after 1996 should have allowed sufficient time for the recovery of fish populations in the closed area and an appropriate test of the spillover effect (Sladek Nowlis and Roberts 1999, McClanahan et al. 2007). Ten years also provided an approximately balanced before and after time to determine the effect of the seine net reduction management that took full effect in 2001. Following the removal of beach seines in South coast sites that began in October 2001, catch monitoring began in the three North coast sites in January 2001 in order to serve as controls for the 
landing sites that removed beach seines. The same two data collectors (Kitema and Mutisya) were used for the entire 10 years, and they were regularly monitored for consistency in catch recording methods in order to decrease potential observer bias. When data were misidentified or entered incorrectly $(<2 \%)$, they were removed prior to the data analysis.

At each landing site, standard methods were used to record gear use by the fishers and landed fish catch. Each landing site was sampled between two and 10 days per month for a total of 3190 sampling days. On each sampling day, the number of fishers per gear, the entire catch by gear, taxonomic groups, and landing site was recorded. Landed fish were identified to six major groups: (1) goatfish (Mullidae), (2) parrotfish (Scaridae), (3) rabbitfish (Siganidae), (4) scavengers (Lethrinidae, Lutjanidae, and Haemulidae), (5) octopus, and (6) a "mixed" category of species common in the catch but not easily classified or not willingly separated into groups by the fishers. Large catches of fish outside of these groups were identified to the species and recorded. The wet mass of each group was estimated to the nearest $0.5 \mathrm{~kg}$ using a spring balance.

\section{Fishery pressure and yields}

We calculated several indices of fishing pressure, gear use, and catch. Fishing intensity was calculated as a total number of fishers per square kilometer of fishing ground. Fishing areas were calculated by incorporating previous studies involving discussions with fishers (McClanahan and Mangi 2001, Cinner et al. 2008) with satellite imagery, GPS positions, and spatial calculation functions in ArcView 3.2 (ESRI 1999). We used wet masses to calculate total catch $\left(\mathrm{Mg} \cdot \mathrm{km}^{-2} \cdot \mathrm{yr}^{-1}\right)$ and catch per unit effort (CPUE: $\mathrm{kg} \cdot$ fisher ${ }^{-1} \cdot \mathrm{d}^{-1}$ ) at each landing site. Catch stability was calculated as the coefficient of variation for CPUE $\left(\mathrm{CV}_{\mathrm{CPUE}}=\mathrm{CPUE}\right.$ standard deviation/CPUE mean $\times 100 \%$ ).

Information about trophic level designations for commonly targeted species was taken from FishBase (Froese and Pauly 2000) and averaged to calculate a mean trophic level for each of the major catch groups. We calculated the mean trophic level of the catch by landing site on each sampling day $(k)$ as

$$
\mathrm{TL}_{k}=\frac{\sum_{i=1}^{m} Y_{i k} \mathrm{TL}}{\sum Y_{i k}}
$$

where $Y_{i k}$ is the catch of group $i$ on day $k$, and TL is the trophic level of group $i$ for $m$ trophic groups (Pauly et al. 2001). The mean trophic level of the "mixed" group was not calculated because it is made up of unidentified species and this group was not included in further trophic level or functional group analyses. Catch was analyzed on a functional group level, whereby fish families were classified as herbivores or carnivore consumers using diet composition data available on
FishBase (Froese and Pauly 2000). Octopus catch was not included with the fish functional groups and was classified as a separate functional group. Information on trophic level and functional group classification for each major catch group is summarized in the Appendix.

\section{Classifications and statistical analyses of catch}

To understand the effect of closed area and gear restriction management on fishery yields, we classified landing sites into three different management areas based on the proportion of gear use from cluster analyses. These were North coast (Marina, Mtwapa, Nyali), South coast (Tradewinds, Mwaepe, Mvuleni, Mwanyaza, Mgwani, Chale), and Kenyatta beach. These classifications were based on a hierarchical agglomerative clustering of gear use at each landing site, which prioritizes similarities rather than differences between samples and no prior assumptions are made about the types of individuals in the samples (Underwood 1997). Gear use composition was averaged by gear by site over the 10-year period to detect the main associations in the data. Change in the catch composition over time with each management group was evaluated using canonical correspondence analyses where eigenvectors were overlaid on the resultant plot to define the direction and contribution of each gear type along the axes (ter Braak 1986).

To examine the association of trends in catch with management strategies, we used a three-way factorial ANCOVA design. Fishing effort (no. fishers $\cdot \mathrm{km}^{-2} \cdot \mathrm{d}^{-1}$ ) was used as a covariate in all models because it is a standardized measure of fishing intensity. Management was assessed at each landing site every year (thus the unit of replication is landing site per year) and was split into two factors, presence of protected areas $<5 \mathrm{~km}$ from the landing site, which is within the measured $\sim 3-\mathrm{km}$ adult spillover (McClanahan and Mangi 2000), and the status of beach seine restriction. Using this ANCOVA design, we tested three main effects: CPUE, catch variability $\left(\mathrm{CV}_{\mathrm{CPUE}}\right)$, and trophic level of the catch and their interactions. Data were tested for normality and homogeneity of variances with ShapiroWilk's and Levene's tests, respectively (Underwood 1997). To increase normality, fishing effort and mean trophic level of catch were Box-Cox transformed ( $y=$ $x^{\lambda}$ where $\lambda=0.3$ for effort and $\lambda=1.9$ for trophic level) and CPUE CV was square-root transformed. It was not possible to achieve a normal distribution for CPUE through transformations so an ordinal logistic MANOVA, which is more robust to deviations from normality, was performed in the place of the ANCOVA. A significance level of 0.05 was used in all statistical tests and post hoc analysis of means was undertaken using a Tukey hsd (Underwood 1997).

To quantify the effects of different management strategies on catch, we performed residual analysis on the regression models of fishing effort by total catch, CPUE, $\mathrm{CV}_{\mathrm{CPUE}}$, and trophic level. We classified each 
a
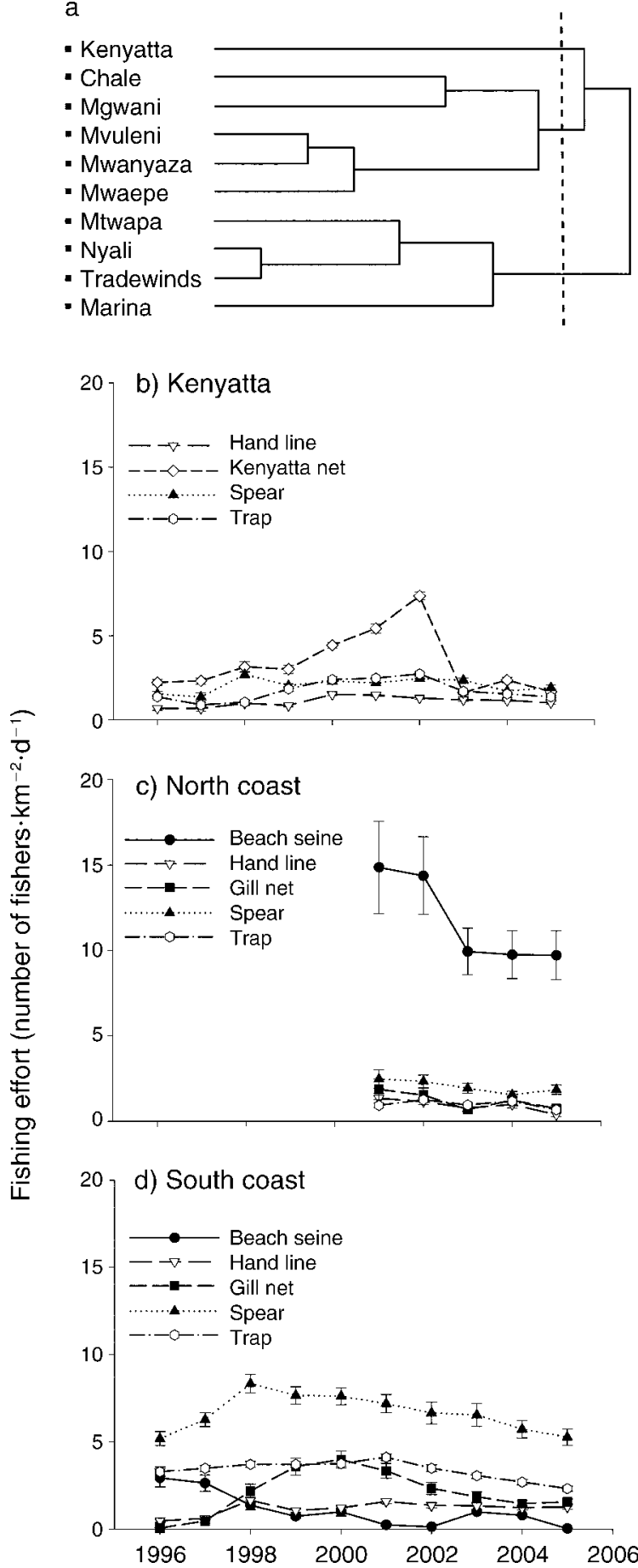

FIG. 2. (a) Cluster analysis based on gear use and each landing site; the dashed vertical line indicates the level of similarity used to distinguish the three management groups. Fishing effort (mean \pm SE) within each gear type between 1996 and 2005 is shown for each of the three management groups identified by the cluster analysis: (b) Kenyatta, (c) North coast, and (d) South coast. Note that the Kenyatta net is a pulled seine net, reluctantly modified by fishers to satisfy the park service's efforts to eliminate beach seine use; it is distinct from the net gear (gill nets) depicted for the North and South coasts. landing site into a protection status ("near park" if situated $<5 \mathrm{~km}$ from a fishery exclosure vs. "far from park") and a beach seine status ("beach seine excluded" vs. "beach seine in use") at each year between 1996 and 2005. We then calculated the mean and standard error of the residuals for each management category. We investigated how these residual values scaled up into annual trends by multiplying each residual (based on daily values) by 220 fishing days (e.g., McClanahan and Mangi 2001) to estimate an annual value of subsidy to the fishery from area closures vs. destructive gear management.

\section{Gear diversity and yield}

The diversity of gear in a fishery is hypothesized to be a measure of the partitioning of the catch by fishers and is expected to estimate the degree of competition for resources; lower gear diversity reflecting competition for resources and competitive exclusion (McClanahan and Mangi 2004). Gear diversity was calculated using a modification of the Simpson diversity index $(D)$ using the formula $D=1-\Sigma p_{i}^{2}$, where $p$ is the proportion of fishers using each specific gear, $i$, divided by the total number of fishers at the landing site. $D$ ranges from 0 , the lowest, to 1 , the highest measure of diversity. Diversity of gear use was calculated for each sampling day and an annual average was calculated for each landing site. The relationship between gear diversity and fishing effort was examined using Pearson correlation analysis, after testing the two variables for normality. The effect of gear diversity on total catch $\left(\mathrm{Mg} \cdot \mathrm{km}^{-2} \cdot \mathrm{yr}^{-1}\right)$, CPUE $\left(\mathrm{kg} \cdot\right.$ fisher $\left.^{-1} \cdot \mathrm{d}^{-1}\right)$, catch stability $\left(\mathrm{CV}_{\mathrm{CPUE}}\right)$, and mean trophic level of catch was examined using linear regressions. For all regressions, we tested for statistical outliers using the Mahalanobis distance test and calculated $95 \%$ confidence intervals around the slope (Underwood 1997). All analyses were performed using JMP statistical software, version 5.0 (SAS Institute, Cary, North Carolina, USA).

\section{Results \\ Landing site classifications}

The three management groups (North coast, South coast, and Kenyatta) were based on proximity to a marine protected area (MPA) and history of gear management (Table 1). Management histories were reflected in the gear-use composition over the 10-year study with sites clustering based on average numbers of fishers in each gear category over the 10-year period (Fig. 2a). Mtwapa, Nyali, Marina, and Tradewinds, all sites with seine net use, clustered separately from sites with no seine net use. Kenyatta then clustered out from the remaining South coast sites at a low level of similarity (Fig. 2b). North coast landing sites had the highest mean fishing effort with 7.2-21.8 fishers $\mathrm{km}^{-2} \cdot \mathrm{d}^{-1}$. High effort at these sites was driven by prevalent beach seine use, with few fishers using other gear types (Fig. 2c). South coast sites showed medium to high levels of fishing 


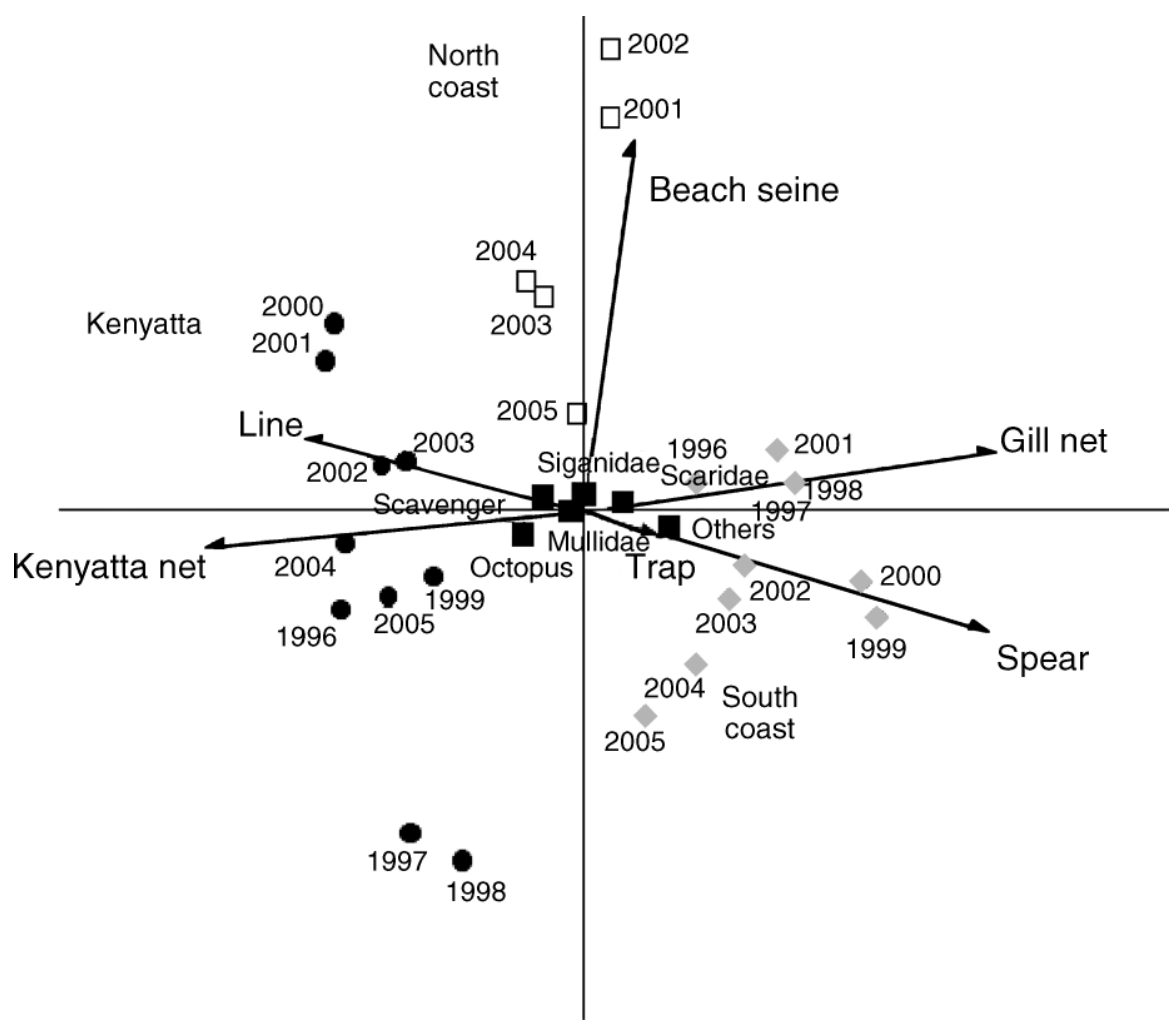

FIG. 3. Canonical correspondence analysis of $\log _{10}$-transformed catch composition $\left(\mathrm{kg} \cdot \mathrm{fisher} \mathrm{r}^{-1} \cdot \mathrm{d}^{-1}\right.$ ) with overlay of eigenvectors of effort (number of fishers $/ \mathrm{km}^{2}$ ) by gear. Symbols represent management groups by year (solid circles, Kenyatta; open squares, North coast; gray diamonds, South coast). Numbers associated with each symbol indicate the year (1996-2005). Black squares are the positions of the fish families in this space. All other symbols are site-years.

pressure from 4.8 to 21.5 fishers $\cdot \mathrm{km}^{-2} \cdot \mathrm{d}^{-1}$ and a more even distribution of fishers across the main gears (Fig. 2d). Fishing effort was moderate at the Kenyatta landing site; mean effort was 7.2 fishers $\cdot \mathrm{km}^{-2} \cdot \mathrm{d}^{-1}$ and was distributed evenly across the main gears other than a period of high-intensity netting from 2000 to 2002 (Fig. 2b).

Shifts in the catch composition were observed from 1996 to 2005 across all treatments. Canonical correspondence analysis showed North coast sites distinct from all other sites and driven by beach seine use. Over time, with no change in gear use, catch composition became less distinct and had a greater overlap with other gear types, typified by Scaridae and Siganidae catches (Fig. 3). South coast sites showed a gradual shift over time from Scaridae, toward increases in octopus and Mullidae, driven by spear and trap fishing and away from beach seine use and catch (Fig. 3). Prior to 2002, catch composition in Kenyatta was variable from year to year; the last four years indicate more stability in the catch, driven by Kenyatta net and handline catches characterized by scavengers (Fig. 3).

\section{Fishing effort and catch}

Mean fishing pressure by the three management areas ranged from 5.2 to 21.8 fishers $\cdot \mathrm{km}^{-2} \cdot \mathrm{d}^{-1}$ and was associated with differences in gear use across the study sites (Table 2). Fishing effort at individual landing sites ranged from 4.9 to 30.3 fishers $\cdot \mathrm{km}^{-2} \cdot \mathrm{d}^{-1}$; high effort was primarily driven by the use of seine nets, which were

TABLE 2. Gear use as a function of fishing effort in a complex multi-gear artisanal coral reef fishery in Kenya.

\begin{tabular}{llrrrc}
\hline \hline \multicolumn{1}{c}{ Gear } & \multicolumn{1}{c}{ Regression equation } & $R^{2}$ & $F$ & $\mathrm{df}$ & \multicolumn{1}{c}{$P$} \\
\hline Beach seine & $y=-113.01+15.34 x-0.31 x^{2}$ & 0.41 & 5.18 & 2,14 & $<0.02$ \\
Hand line & $y=21.48-1.13 x+0.02 x^{2}$ & 0.22 & 10.64 & 2,69 & $<0.0001$ \\
Kenyatta net & $y=23.43+1.95 x$ & 0.43 & 6.76 & 2,9 & $<0.03$ \\
Gill net & & & & NS \\
Spear & $y=-11.85+8.73 x-0.58 x^{2}+0.001 x^{3}$ & 0.33 & 12.95 & 2,74 & $<0.0001$ \\
Trap & & & & & $<1$ \\
\end{tabular}

Notes: Data are plotted in Fig. 4a. An entry of "NS" in the last column indicates that the relationship was not statistically significant $(P>0.05)$. 

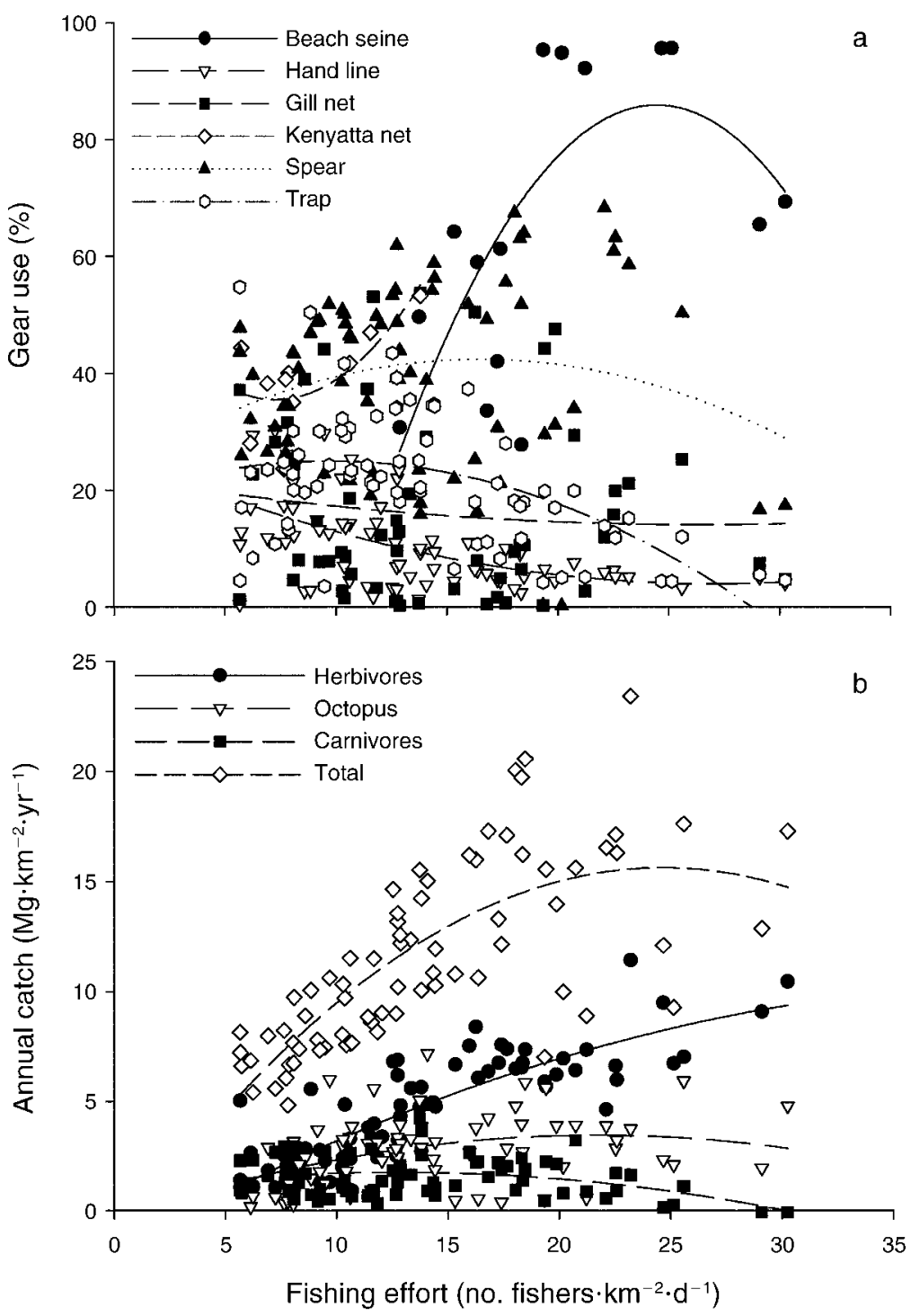

FIG. 4. The relationship between fishing effort and fishery catch in the Kenyan artisanal fishery by (a) percentage use of gear types and (b) annual catch by functional group and in total. Sampling units are landing sites by year.

uncommon at low fisher densities but became the dominant gear when there were more than 12 fish$\mathrm{ers} / \mathrm{km}^{2}$. Line fishing and traps declined steadily with increasing effort with maximum use at $\sim 12$ fishers $/ \mathrm{km}^{2}$. Kenyatta net increased linearly up to 12 fishers $/ \mathrm{km}^{2}$; however, this was only represented in one site (Kenyatta beach). Spear gun and passive net use was variable and had no significant association with fishing density (Fig. 4a). Best-fit curves indicate that the relationship between effort and use was different for each gear type (Table 2).

The total annual catch and catch by functional groups also displays strong trends with fishing effort (Fig. 4b). Composition of the catch was associated with fishing pressure; carnivores declined to near zero at low levels of effort followed by octopus and both were replaced by an increasing proportion of herbivorous fishes at the highest effort where the total catch plateau at $\sim 16$ $\mathrm{Mg} \cdot \mathrm{km}^{-2} \cdot \mathrm{yr}^{-1}$ (octopus, $R^{2}=0.17, P<0.001$; carnivores, $R^{2}=0.20, P<0.0001$; herbivores, $R^{2}=0.75, P<$ 0.0001; Fig. 4b).

CPUE $\left(R^{2}=0.59, P<0.0001\right.$; Fig. 5a) and trophic level of the catch $\left(R^{2}=0.66, P<0.0001\right.$; Fig. 5d) were negatively associated with fishing effort, while positively associated with catch variability $\left(\mathrm{CV}_{\mathrm{CPUE}}, R^{2}=0.17, P\right.$ $=0.048$; Fig. 5b) and annual catch $\left(R^{2}=0.41, P=\right.$ 0.0005; Fig. 5c).

Analysis of the catch by the management classifications for proximity to a fishery closure and beach seine use, fishing intensity, and their interactions, explained significant amounts of variation in CPUE, trophic level, and $\mathrm{CV}_{\mathrm{CPUE}}$ (Table 3). Residual analysis from the linear regression models of fishing effort with total catch, 

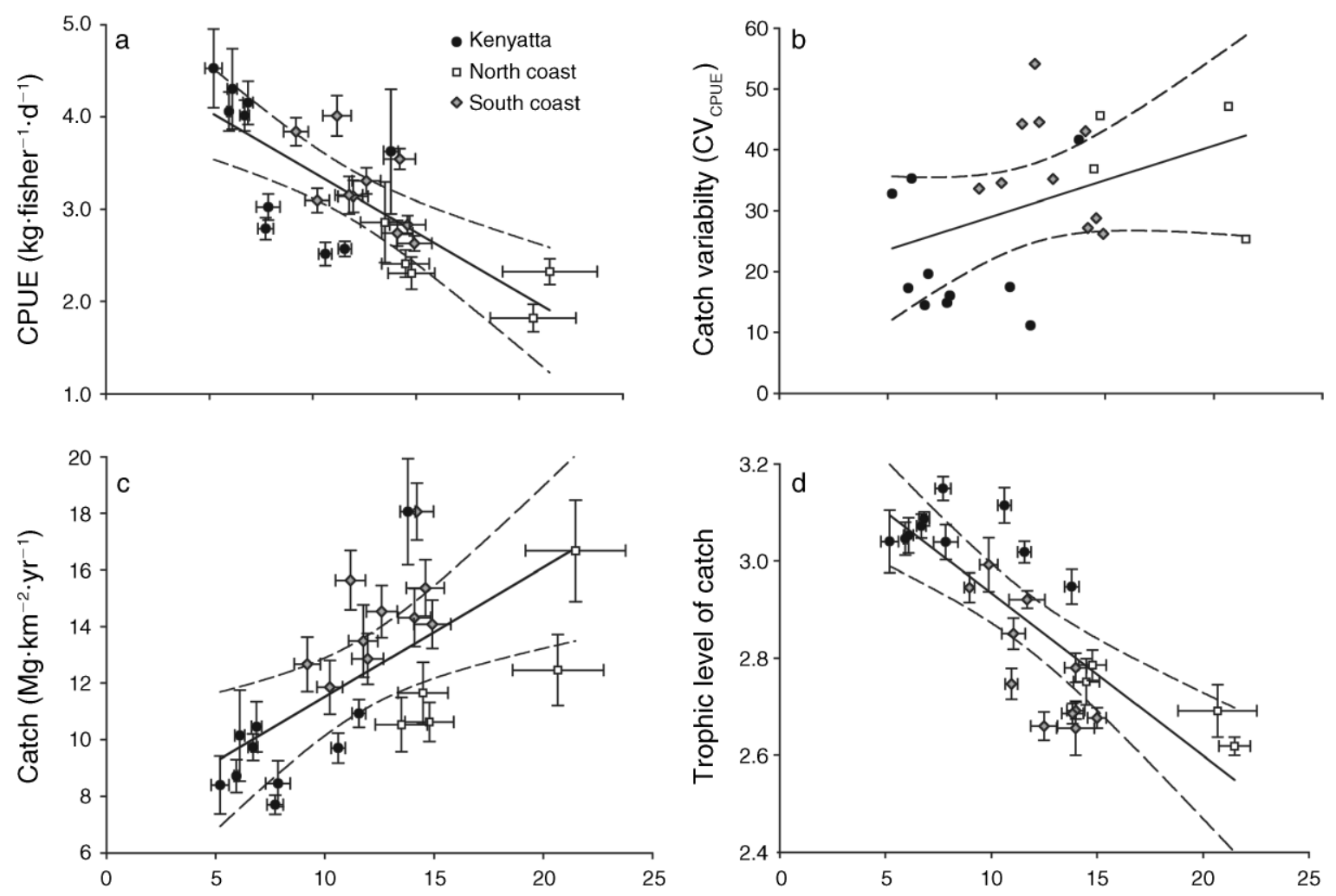

Fishing effort (no. fishers $\cdot \mathrm{km}^{-2} \cdot \mathrm{d}^{-1}$ )

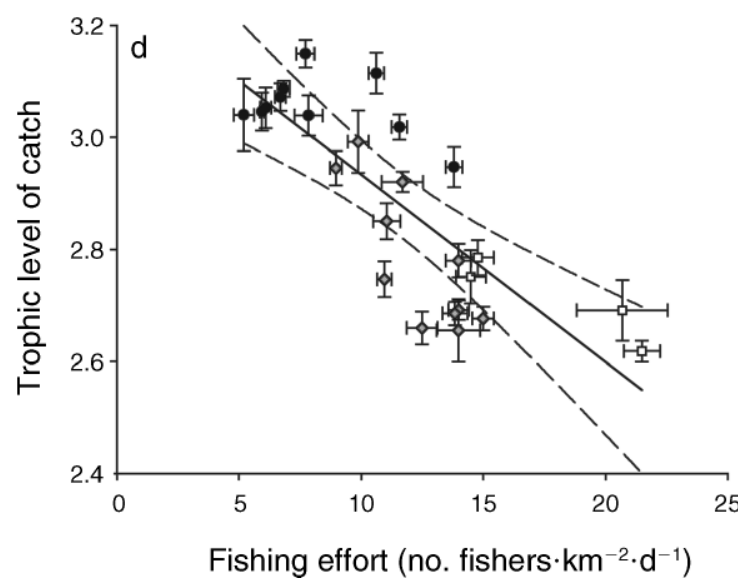

FIG. 5. The relationship between fishing effort and fishery catch in the Kenyan artisanal fishery: (a) CPUE (catch per unit effort), (b) catch variability, $\mathrm{CV}_{\mathrm{CPUE}}$, (c) annual catch $\left(\mathrm{Mg} / \mathrm{km}^{2}\right)$ of fishing grounds, and (d) mean trophic level of the catch (see Methods for equation used to calculate mean trophic levels). Sampling units are management group by year. Values are given as means $\pm \mathrm{SE}$; the solid line is the regression of the mean, and dashed lines are $95 \%$ confidence limits.

CPUE, $\mathrm{CV}_{\mathrm{CPUE}}$, and trophic level showed that various management conditions were associated with differential benefits and detriments (Table 4$)$. The effect of a fishery closure within $5 \mathrm{~km}$ of the landing was a decrease in total catch and CPUE, and an increase in trophic level and catch stability. Beach seine restriction increased total catch, CPUE, and trophic level. Sites using beach seines had lower catch variability than sites that had excluded beach seine use for the same level of fishing effort.
Differences in total catch, CPUE, catch variability, and trophic level of the catch were pronounced among the three fisheries-management treatments (Kenyatta, North coast, and South coast). These trends were likely explained by variation in fishing effort interacting with gear and closure management among these treatments (Table 4). As fishing effort was nearly equal in the near vs. far MPA treatment and between the seine exclusion vs. seine use treatment, differences in the residual values

TABLE 3. The effect of protected area management, seine net restriction, and fishing intensity on catch per unit effort (CPUE), trophic level of the catch, and catch variability.

\begin{tabular}{|c|c|c|c|c|c|c|}
\hline \multirow[b]{2}{*}{ Effect } & \multicolumn{2}{|c|}{ CPUE } & \multicolumn{2}{|c|}{ Trophic level of catch } & \multicolumn{2}{|c|}{ Catch variability } \\
\hline & $\chi^{2}$ & $P$ & $F$ & $P$ & $F$ & $P$ \\
\hline Area closure management & 19.79 & $<0.001$ & 6.45 & $<0.02$ & 0.41 & NS \\
\hline Seine net restriction & 12.35 & $<0.0005$ & 107.61 & $<0.0001$ & 14.42 & $<0.0002$ \\
\hline Fishing effort & 17.47 & $<0.0001$ & 4.01 & $<0.05$ & 34.90 & $<0.0001$ \\
\hline Area closure $\times$ seine restriction & 7.17 & $<0.01$ & 96.87 & $<0.0001$ & 12.50 & $<0.0004$ \\
\hline Area closure $\times$ fishing effort & 6.26 & $<0.02$ & 0.32 & NS & 7.05 & $<0.01$ \\
\hline Seine restriction $\times$ fishing effort & 0.43 & NS & 6.53 & $<0.02$ & 0.48 & NS \\
\hline Area closure $\times$ seine restriction $\times$ fishing effort & 0.50 & NS & 16.51 & $<0.0001$ & 0.86 & NS \\
\hline
\end{tabular}

Note: For all analyses, $\mathrm{df}=1,953$. 
TABLE 4. Daily and annual subsidy effects of area closure and gear restriction management on total catch, $\mathrm{CPUE}_{\mathrm{C}} \mathrm{CV}_{\mathrm{CPUE}}$, and trophic level of the artisanal coral reef fishery in Kenya.

\begin{tabular}{|c|c|c|c|c|c|c|}
\hline \multirow[b]{2}{*}{ Effect } & \multirow[b]{2}{*}{$N$} & \multirow[b]{2}{*}{$\begin{array}{l}\text { Fishing effort } \\
\text { (no. fishers } / \mathrm{km}^{2} \text { ) }\end{array}$} & \multicolumn{4}{|c|}{ Residual analysis } \\
\hline & & & $\begin{array}{c}\text { Total catch } \\
\left(\mathrm{kg} \cdot \mathrm{km}^{-2} \cdot \mathrm{d}^{-1}\right)\end{array}$ & $\begin{array}{c}\text { CPUE } \\
\left(\mathrm{kg} \cdot \text { fisher }^{-1} \cdot \mathrm{d}^{-1}\right)\end{array}$ & $\begin{array}{c}\text { Catch variability, } \\
\mathrm{CV}_{\text {CPUE }}(\%)\end{array}$ & $\begin{array}{l}\text { Trophic level } \\
\text { of catch }\left(\mathrm{d}^{-1}\right)\end{array}$ \\
\hline \multicolumn{7}{|l|}{ Management type } \\
\hline Near MPA $(<5 \mathrm{~km})$ & 25 & $13.63 \pm 1.59$ & $-6.63 \pm 1.99$ & $-0.23 \pm 0.15$ & $-2.34 \pm 3.00$ & $0.04 \pm 0.04$ \\
\hline Far from MPA $(>5 \mathrm{~km})$ & 60 & $12.83 \pm 0.74$ & $2.76 \pm 1.09$ & $0.10 \pm 0.08$ & $0.97 \pm 1.44$ & $-0.02 \pm 0.02$ \\
\hline Beach seine excluded & 39 & $12.71 \pm 0.71$ & $5.43 \pm 1.31$ & $0.30 \pm 0.09$ & $1.84 \pm 2.13$ & $0.02 \pm 0.03$ \\
\hline Beach seine in use & 46 & $13.34 \pm 1.14$ & $-4.60 \pm 1.30$ & $-0.25 \pm 0.09$ & $-1.56 \pm 1.69$ & $-0.02 \pm 0.03$ \\
\hline \multicolumn{7}{|l|}{ Management group } \\
\hline Kenyatta & 10 & $8.28 \pm 0.88$ & $0.29 \pm 1.67$ & $0.17 \pm 0.21$ & $-11.60 \pm 3.38$ & $0.15 \pm 0.02$ \\
\hline North coast & 15 & $17.21 \pm 2.15$ & $-11.24 \pm 2.51$ & $-0.50 \pm 0.17$ & $3.84 \pm 3.73$ & $-0.03 \pm 0.06$ \\
\hline South coast & 60 & $12.83 \pm 0.74$ & $2.76 \pm 1.09$ & $0.10 \pm 0.08$ & $0.97 \pm 1.44$ & $-0.02 \pm 0.02$ \\
\hline
\end{tabular}

Notes: Values shown are mean residual \pm standard error. Annual subsidies are calculated as daily residual value $\times$ annual average of 220 days of fishing effort. "MPA" indicates a marine protected area. Sample size $(N)$ is number of landing sites by year.

of the catch were likely to be real and not an artifact of nonlinear relationships with fishing pressure.

\section{Gear diversity}

Gear diversity was negatively associated with fishing effort ( $r=-0.72, P<0.0001$; Fig. 6a), total annual catch $\left(R^{2}=0.26, P=0.013\right.$; Fig. $\left.6 \mathrm{~b}\right)$, and catch variability $\left(\mathrm{CV}_{\mathrm{CPUE}}, R^{2}=0.50, P<0.0001\right.$; Fig. $\left.6 \mathrm{~d}\right)$. Gear diversity was positively associated with $\operatorname{CPUE}\left(R^{2}=0.28, P=\right.$ 0.006 ; Fig. 6c) and mean trophic level of the catch $\left(R^{2}=\right.$ 0.69, $P<0.0001$; Fig. 6e).

\section{Fishery recovery with management}

Ten-year trends in CPUE showed a rapid response to changes in management (Fig. 7). The daily catch per fisher in 1996, at the start of our study, was 4.3 $\mathrm{kg} \cdot$ fisher ${ }^{-1} \cdot \mathrm{d}^{-1}$ in Kenyatta and $3.9 \mathrm{~kg} \cdot \mathrm{fisher}^{-1} \cdot \mathrm{d}^{-1}$ in the South coast. These values declined for four years to 2.6 $\mathrm{kg} \cdot$ fisher $^{-1} \cdot \mathrm{d}^{-1}$ and $2.5 \mathrm{~kg} \cdot \mathrm{fisher}^{-1} \cdot \mathrm{d}^{-1}$ for South coast and Kenyatta beach landing sites in 2000, respectively. Following the removal of beach seines from Mwaepe in 1997 and Mgwani in 1999 the decline in CPUE in the South coast halted. A marked turning point occurred in 2001 for the South coast with CPUE increasing initially to $3.5 \mathrm{~kg} \cdot$ fisher $^{-1} \cdot \mathrm{d}^{-1}$, dropping slightly in 2002 before steadily increasing to $3.9 \mathrm{~kg} \cdot \mathrm{fisher}^{-1} \cdot \mathrm{d}^{-1}$ in 2005 , changes that are associated with the elimination of seine nets in the remaining sites in Chale in 2001 and Tradewinds in 2005. Kenyatta followed a similar pattern increasing to $3.6 \mathrm{~kg} \cdot \mathrm{fisher}^{-1} \cdot \mathrm{d}^{-1}$ in 2002 with a reduced use of seine nets (Fig. 2b) and then stabilizing at $4.0 \mathrm{~kg} \cdot \mathrm{fisher}^{-1} \cdot \mathrm{d}^{-1}$ in 2005. North coast landing sites that were monitored as controls for the South coast changes, maintained a CPUE yield of $\sim 2.3 \mathrm{~kg} \cdot$ fisher ${ }^{-1} \cdot \mathrm{d}^{-1}$. While CPUE dropped slightly in 2002, there was no significant change in CPUE between 2001 and $2005\left(F_{4,10}=0.45, P=0.77\right.$; Fig. 7).

\section{Discussion}

This study describes a mature, but spatially variable, fishery in southern Kenya where fishing effort was high
( 5-30 fishers $\left.\cdot \mathrm{km}^{-2} \cdot \mathrm{d}^{-1}\right)$, CPUE was low (1.5-4.5 $\mathrm{kg} \cdot$ fisher $\left.^{-1} \cdot \mathrm{d}^{-1}\right)$, but total catch remained high $(\sim 3-16$ $\left.\mathrm{Mg} \cdot \mathrm{km}^{-2} \cdot \mathrm{yr}^{-1}\right)$. The catch was primarily composed of herbivorous fishes that feed on seagrass (Leptoscarus and Siganus) and largely caught by seine nets (McClanahan and Mangi 2004). From the Malthusian view of overexploitation, there were clear patterns in the decline of resources, yield stability, trophic levels, and the disappearance of key functional groups along the gradient of fishing effort (Fig. 5). Field surveys, in many of these sites, have also shown large declines in biodiversity (McClanahan et al. 2007). The social phenomenon that co-occurs or causes this decline was reflected primarily in the dominance of seine nets (Fig. $4 \mathrm{a}$, Table 2) and reduced gear diversity (Fig. 6). The ecological decline of the fishery along the effort gradient was paralleled by a number of social-ecological system (SES) responses that might be expected by both a Malthusian view of overexploitation and those that might develop to moderate the negative effects of competition for a diminishing common-pool resource (Dietz et al. 2003). Area closures and comanagement efforts to reduce illegal/destructive gear use are two social organization activities that attempted to counter this trend of diminishing diversity and personal returns on fishing effort (McClanahan 2007).

We evaluated and quantified the effects of area closures and gear management in arresting the decline of this fishery. When effort was controlled for in the residual analysis, area closures decreased fishery yield and CPUE for adjacent landing sites, while stabilizing the yield $\left(\mathrm{CV}_{\mathrm{CPUE}}\right)$ and increasing the trophic level of the catch (Table 4). A previous study comparing the before/after effect of area closures found reduced yields but increased CPUE after closure (McClanahan and Mangi 2000). This study confirms our reduced yield result but conflicts with the increase in the CPUE reported previously in Mombasa and the Malindi and Watamu MNP closures (Kaunda-Arara and Rose 2004). A before-and-after comparison is a more powerful experimental technique than the spatial comparison 
TABLE 4. Extended.

\begin{tabular}{|c|c|c|}
\hline \multicolumn{3}{|c|}{ Annual subsidy } \\
\hline $\begin{array}{c}\text { Total catch } \\
\left(\mathrm{Mg} \cdot \mathrm{km}^{-2} \cdot \mathrm{yr}^{-1}\right)\end{array}$ & $\begin{array}{c}\text { CPUE } \\
\left(\mathrm{kg} \cdot \text { fisher }^{-1} \cdot \mathrm{yr}^{-1}\right)\end{array}$ & $\begin{array}{c}\text { Catch variability, } \\
\mathrm{CV}_{\text {CPUE }}(\%)\end{array}$ \\
\hline $\begin{array}{r}-1.46 \\
0.61 \\
1.19 \\
-1.01\end{array}$ & $\begin{array}{r}-50.60 \\
22.00 \\
66.00 \\
-55.00\end{array}$ & $\begin{array}{r}-514.80 \\
213.40 \\
404.80 \\
-343.20\end{array}$ \\
\hline $\begin{array}{r}0.06 \\
-2.47 \\
0.61\end{array}$ & $\begin{array}{r}37.40 \\
-110.00 \\
22.00\end{array}$ & $\begin{array}{r}-2552.00 \\
844.80 \\
213.40\end{array}$ \\
\hline
\end{tabular}
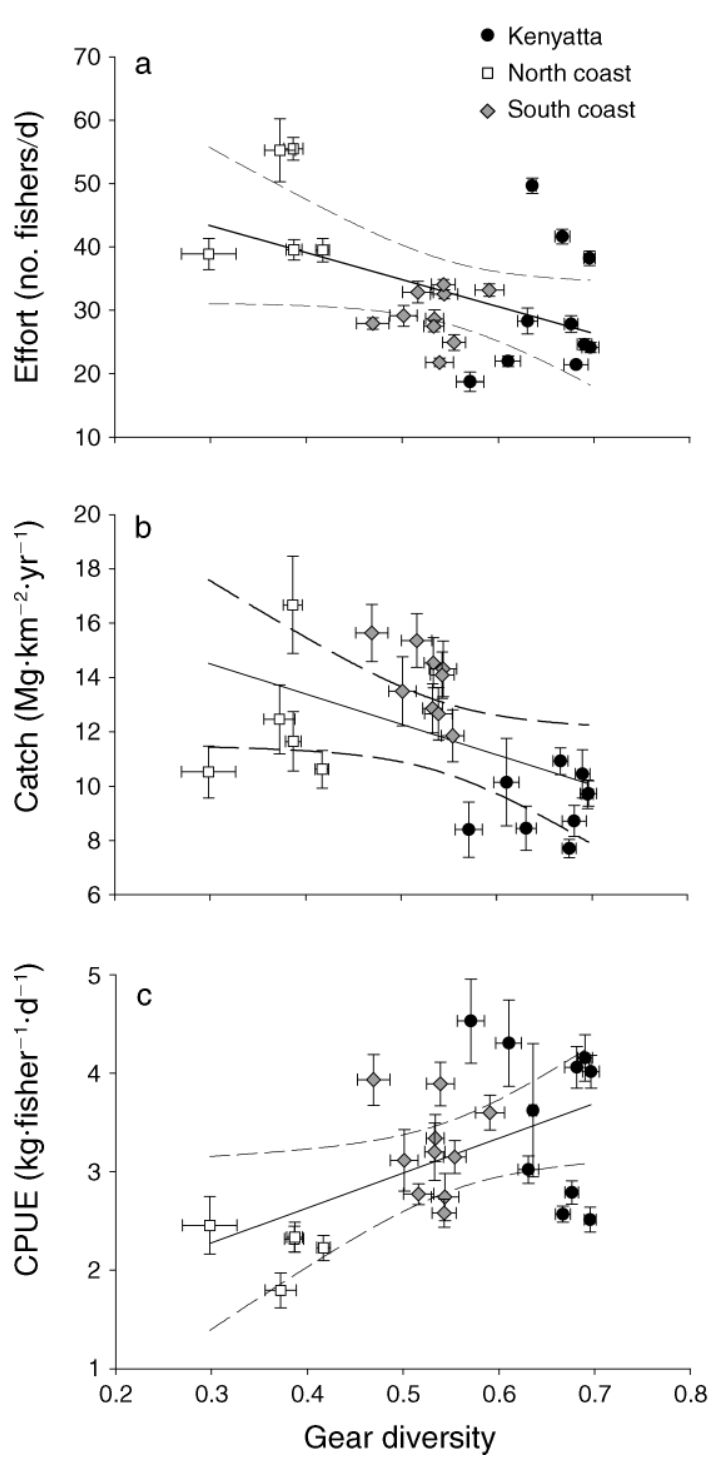

used here, and should take priority in establishing conclusions (Underwood 1994). The pattern found here might be due to inherently lower productivity in the area surrounding the fisheries closure, but also because previous studies have been undertaken in areas without seine nets. The effects of closure on CPUE may, therefore, interact with gear use on the periphery of the closure (McClanahan and Mangi 2000). Nevertheless, it does suggest that closure effects on CPUE may be quite small and restricted to areas close to the closure boundary. Fishing effort, gear use, and fishers' movements may also influence closure effects, which has also been suggested for a small closure in the Philippines (Abesamis et al. 2006). One of the more important roles of Kenya's permanent closures is that they provide more
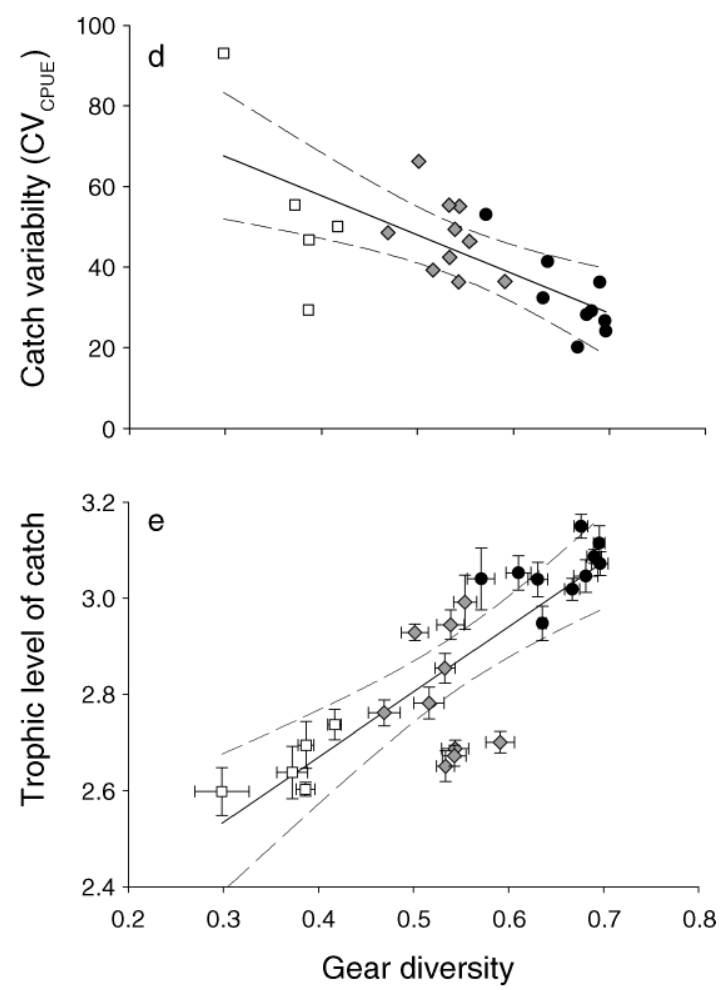

FIG. 6. The relationship between gear diversity and fishery catch in the Kenyan artisanal fishery: (a) fishing effort, (b) annual catch of fishing area, (c) CPUE, (d), catch variability, $\mathrm{CV}_{\mathrm{CPUE}}$, and (e) trophic level of the catch. Sampling units are management group by year. Values are given as means \pm SE; the solid line is the regression of the mean, and dashed lines are $95 \%$ confidence limits. 


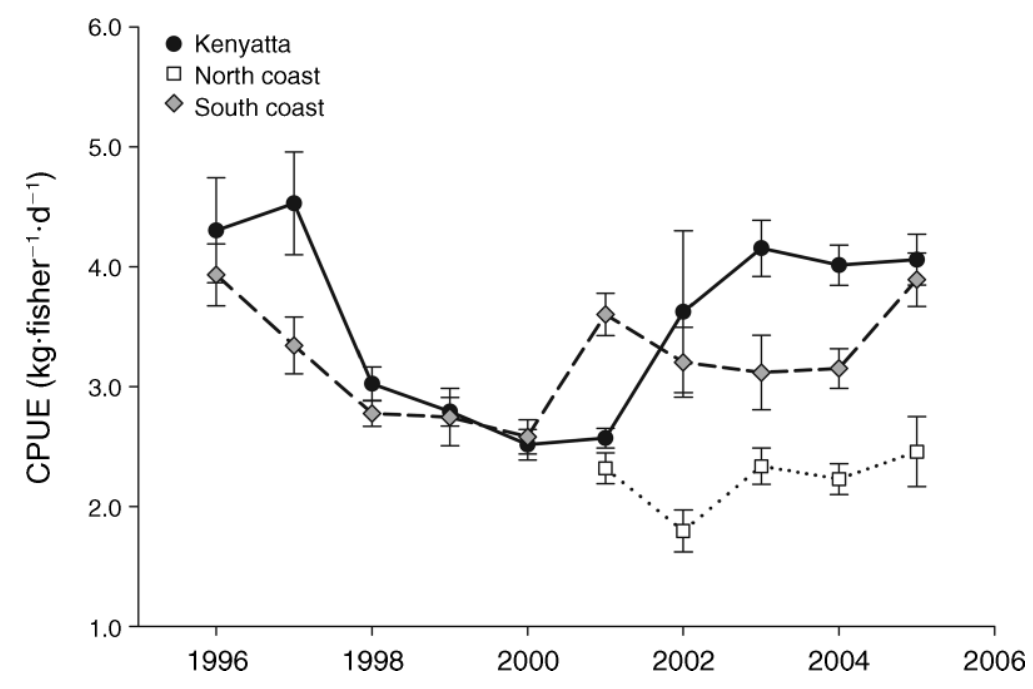

FIG. 7. Ten-year trend (1996-2006) in CPUE (mean \pm SE) of each management group.

biodiversity and other ecological processes than fished areas (McClanahan et al. 2006, 2007), although these indirect effects are not well appreciated by resource users (McClanahan et al. 2005).

In contrast, gear management of illegal seine nets was effective at increasing total yields and CPUE, but not yield stability or the trophic level of the catch (Table 4). Interestingly, this stabilization or increase in CPUE was seen very shortly following the removal of beach seines (Fig. 7), suggesting that stocks can recover quickly following the removal of a gear with a small mesh size. Growth rates of herbivorous fishes based on tag and release studies reported high linear extension growth rates of $\sim 10$ and $\sim 5 \mathrm{~cm} / \mathrm{yr}$ for Siganus sutor and Leptoscarus vaigensis, respectively (Kaunda-Arara and Rose 2006). High growth rates suggest that differences in the size and time to first capture for beach seines and traps are small, possibly less than one year. A long-term positive effect of seine net removal is supported by the high CPUE in landing sites that had reduced or removed seine nets (Fig. 7).

The Kenyatta landing site combines area closure and gear management. The landing site is adjacent to the Mombasa Marine National Park; seine nets were originally removed in 1994, returned in 1999, and then fully removed in 2002. Residual analysis of the Kenyatta catch shows higher residual trophic level and, although the CPUE was high for the effort, it was about one-half of the residual from seine net exclusion where there was no increase in trophic level (Table 4). There could, therefore, be an antagonistic relationship between the increased trophic level created by closures and fishery yields, where the increase of predators inside a closure decreases the abundance of lower trophic level species, such as Scaridae and Siganidae, which are the target species of an adjacent landing site. These observations combined with the large number of significant interaction terms (Table 3 ) indicate the role of variability and complex interactions between trophic level, yields, gear use, and closures as has been found for simple predatorprey-closure models (Micheli et al. 2004).

The ability of fisheries in developing countries to provide food and livelihoods for coastal people is dependent on yields and CPUE in relationship to the population's demand for fish (Newton et al. 2007). Based on these criteria, increasing gear diversity is an important management alternative to area closures, and it is therefore important to understand the social dynamics that drive gear dominance. Seine net use is associated with a change in the composition and the history of the people involved in the fishery. Issues of tradition, fisher age, ethnicity, urbanization, migration, ownership, marketing, economic gains, and the degree of reliance on fishing are all factors involved in this SES transition (McClanahan et al. 1997). The terminal stage of this transition is a high yield of small fast-growing fish that are reliant on a resilient ecosystem, namely sand and seagrass (Valentine and Heck 2005). The majority of seine net fishers do not earn enough income to be permanently employed or support a family. Investors typically own the gear and fishers are day-labor employees and often adolescents. The income from beach seines is generally below the standard of living $(<$ US $\$ 1.5 / \mathrm{d})$ that allows dependence on fishing. Ironically, it is youth, livelihood alternatives, and reliance on the owners that may allow for the maintenance of this gear and a lack of commitment to fishing and the environment (Hoorweg 2008).

We saw that the enforcement of the law and the slow elimination of beach seining were achieved in the more rural area of Kenya's South coast, through the efforts of comanagement, but not in the more urban North coast around the city of Mombasa, and the efforts of a national government institution. It may be that the urban environment provides more livelihood alternatives and less social cohesion, which maintains compet- 

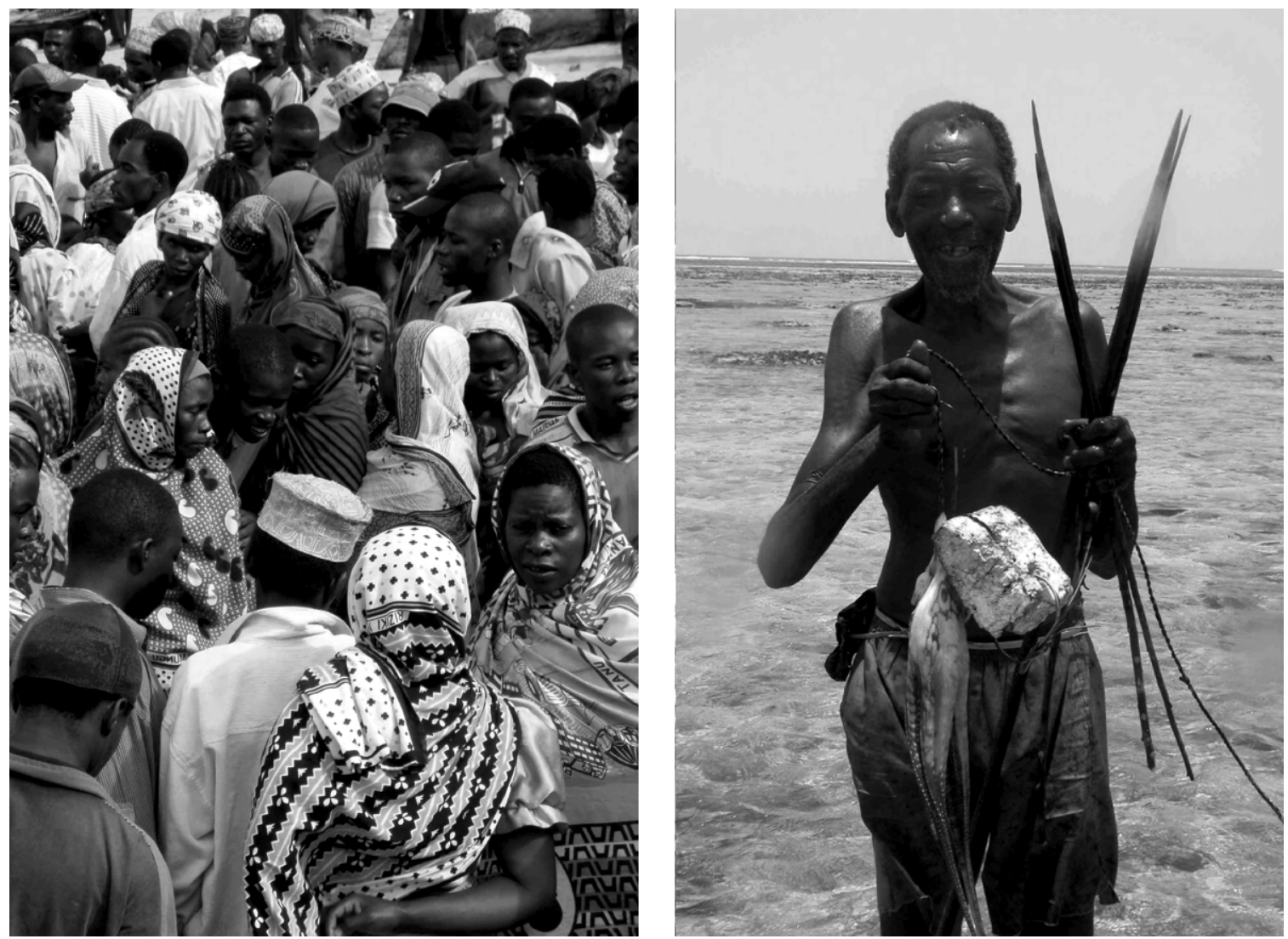

Plate 1. (Left) A fish landing site in East Africa where fish traders have gathered to bargain on the price of landed fish. (Right) Kenyan fisherman with an octopus. Octopus have become one of the major catch items in moderate to heavily exploited reefs, and this may represent the fisher's daily catch. Photo credits: T. A. McClanahan.

itive gear by allowing investors to supply gear that employ fishers with yields that are below what can be sustained by full commitment to the artisanal lifestyle (Hoorweg 2008). It is common to hear artisanal fishers refer to beach seine fishers as non-fishers as they are seen as itinerant day laborers rather than individuals committed to fishing, although many are also migrant fishers that have come from fishing traditions but have left their traditional fishing grounds (McClanahan et al. 1997).

Demographic change and resource use is, in many ways, oversimplified by broad views associated with terms such as overexploitation and a Malthusian tragedy. The fishery was able to maintain effort up to 30 fishers $\mathrm{km}^{-2} \cdot \mathrm{d}^{-1}$ without declines in the total catch but with considerable change in SES. In principle, the system is producing food although at cost to nonanimal production aspects of the SES. At this high level of effort the SES is essentially a simple seagrass-herbivorefisher food chain, a SES where nearly all animal productivity is channeled into a single capture system, and the diversity of gear, fishers, coral reef habitat, and diversity are reduced to low levels. If measured by the standards of animal production, the SES can be seen as successful but, if measured by standards of social and ecological diversity, it would be classified as a tragedy (Feeny et al. 1990).

The fish production measured here of $\sim 16$ $\mathrm{Mg} \cdot \mathrm{km}^{-2} \cdot \mathrm{yr}^{-1}$ (mean $\pm \mathrm{SE}$ ) is among the highest reported for coral reefs in the Indian Ocean. The average of eight Indian Ocean coral reef studies was $3.8 \pm 4.1 \mathrm{Mg} \cdot \mathrm{km}^{-2} \cdot \mathrm{yr}^{-1}$, the global average was $6.6 \pm$ $9.0 \mathrm{Mg} \cdot \mathrm{km}^{-2} \cdot \mathrm{yr}^{-1}$ from 33 sites distributed around the world (McClanahan 2006), and $5 \mathrm{Mg} \cdot \mathrm{km}^{-2} \cdot \mathrm{yr}^{-1}$ is often used to assess sustainability (Newton et al. 2007). A study of the recovery of fish biomass in the Mombasa MNP during the early years of closure estimated a recovery of $14-16 \mathrm{Mg} \cdot \mathrm{km}^{-2} \cdot \mathrm{yr}^{-1}$ during the first few years after closure and where the initial biomass is $<250$ $\mathrm{kg} / \mathrm{ha}$ or $20 \%$ of pristine biomass $\left(B_{0}\right)$ (McClanahan et al. 2007). This is essentially the same as the yields reported here and the value of $\sim 16 \mathrm{Mg} \cdot \mathrm{km}^{-2} \cdot \mathrm{yr}^{-1}$ probably represents a maximum production rate for this area because the shape of the early recovery curve was better represented by saturation (Ricker curve) than a sigmoid response.

Maximum net production at intermediate biomass is the common assumption of standard maximum sus- 
tained fisheries models (Clark 1985) but, if populations follow saturation or a Ricker curve response, the production will be maximized at lower biomass, and this is often found in yield-per-recruit models (Quinn et al. 1990). Consequently, if maximizing fisheries production is the main focus of management, then this study shows that this is possible at very low biomass, even lower than the $20-50 \%$ of pristine biomass that is predicted by sigmoid or yield-per-recruit models (Quinn et al. 1990). This lack of a decline in yields at low biomass has been seen in other tropical fisheries (Lae 1996). This phenomenon is also represented by an unchanged low biomass for a large range of fishing efforts and yields in coral reefs, usually $>2$ fishers $\cdot \mathrm{km}^{-2} \cdot \mathrm{yr}^{-1}$ (Jennings et al. 1995, Jennings and Polunin 1996). Yield results fit reasonably with the unrestricted fishing scenario of the energetic simulation model of coral reefs where maximum yields of purely herbivorous fish are predicted at $\sim 20$ fishers $/ \mathrm{km}^{2}$ (McClanahan 1995). The simulation model predicts modestly well the effort at which yields are maximized but overpredicts actual yields by about a factor of two, probably due to the model's unconfirmed estimates of benthic production, the exclusion of seagrass, and no loss of production from the food web. Under the unrestricted fishing scenario, the loss of herbivore biomass led to the dominance by sea urchin grazers, but the model did not include seagrass production, where dominance by sea urchins is probably not as common or slower to dominate than reported for coral reefs (Valentine and Heck 2005).

An analysis of many animal populations suggests that high or maximum production at low abundance is common (Sibly et al. 2005) and, in high diversity systems such as coral reefs, fishing is likely to select for species that have these population attributes. High production of a few key target species at low biomass creates a dilemma for management where a trade-off between animal production and other SES factors such as biodiversity, habitat, ecological processes, stability of catch, human equity, and protection of traditions and traditional resource users are to be factored into management decisions (Matsuda and Abrams 2006). This study suggests that it is not possible to have maximum production and these other SES aspects without some within-site trade-offs or spatial partitioning of the uses of the resource. Spatial partitioning among gear uses and closures is what developed toward the end of this study.

This study reflects the complexity of SES around fisheries in tropical ecosystems and the difficulties of making recommendations without considering tradeoffs for both people, their organization around resources, and ecosystems. Encouraging a diversity of gear and exclusion of competitively dominant gears will allow the persistence of traditional gear use and associated people, which can maintain high CPUE, but at some cost to maximizing total yields and reducing part-time fishers and investors in these gears. The currently evolving management system in Kenya has produced a complex variety of these options, many of which have resulted from fisheries and closure science combined with a trial and error process between scientists, managers, and resource users. This situation continues to change and is unlikely to be replaced by a top-down, bottom-up, dataless, or data-rich environment, which will hopefully delay and avoid a potential Malthusian tragedy.

\section{ACKNOWLEDGMENTS}

Research and comanagement efforts were supported by the Wildlife Conservation Society through grants from the Tiffany, Eppley, and McBean Foundations and the Pew Fellows Program in Marine Conservation. Research clearance was provided by Kenya's Ministry of Science and Technology, and data collection and management efforts were provided by Kenya's Fisheries Department and Kenya Wildlife Services. S. Mangi, J. Maina, Kitema, and P. Mutisya assisted with the fisheries data collection, and M. Ateweberhan assisted with data analysis. We are grateful to the many fishers and fisheries officers who assisted with data collection and comanagement efforts.

\section{Literature Cited}

Abesamis, R. A., A. C. Alcala, and G. R. Russ. 2006. How much does the fishery at Apo Island benefit from spillover of adult fish from the adjacent marine reserve? Fisheries Bulletin 104:360-375.

Armitage, D., and D. Johnson. 2006. Can resilience be reconciled with globalization and the increasingly complex conditions of resource degradation in Asian coastal regions. Ecology and Society 11:2.

Berkes, F., and C. S. Seixas. 2005. Building resilience in lagoon social-ecological systems: a local-level perspective. Ecosystems 8:967-974.

Cinner, J. E., and T. R. McClanahan. 2006. Socioeconomic factors that lead to overfishing in small-scale coral reef fisheries of Papua New Guinea. Environmental Conservation 33:73-80.

Cinner, J., T. R. McClanahan, C. Abunge, and G. Wamkuta. 2008. A baseline socioeconomic assessment of fishing communities along the north coast of Kenya. In J. Hoorweg and N. A. Muthiga, editors. Coastal ecology. African Studies Centre, Leiden, The Netherlands, in press.

Clark, C. W. 1985. Bioeconomic modelling and fisheries management. Wiley-Interscience, New York, New York, USA.

Dietz, T., E. Ostrom, and P. C. Stern. 2003. The struggle to govern the commons. Science 302:1907-1912.

ESRI (Environmental Systems Research Institute). 1999. ArcView. Version 3.2. ESRI, Redlands, California, USA.

Feeny, D., F. Berkes, B. J. McCay, and J. M. Acheson. 1990. The tragedy of the commons: twenty-two years later. Human Ecology 18:1-18.

Froese, R., and D. Pauly, editors. 2000. FishBases 2000: concepts, design and data source. ICLARM, Makati City, Philippines.

Hoorweg, J. 2008. Income diversification and fishing practices among artisanal fishers. In J. Hoorweg and N. A. Muthiga, editors. Coastal ecology. African Studies Centre, Leiden, The Netherlands, in press.

Jennings, S., E. M. Grandcourt, and N. V. C. Polunin. 1995. The effects of fishing on the diversity, biomass and trophic structure of Seychelles' reef fish communities. Coral Reefs 14: $225-235$.

Jennings, S., and N. V. C. Polunin. 1996. Effects of fishing effort and catch rate upon the structure and biomass of Fijian reef fish communities. Journal of Applied Ecology 33:400412 . 
Kaunda-Arara, B., and G. A. Rose. 2004. Effects of marine reef National Parks on fishery CPUE in coastal Kenya. Biological Conservation 118:1-13.

Kaunda-Arara, B., and G. A. Rose. 2006. Growth and survival rates of exploited coral reef fishes in Kenyan marine parks derived from tagging and length-frequency data. Western Indian Ocean Journal of Marine Science 5:17-26.

Lae, R. 1996. Does overfishing lead to a decrease in catches and yields? An example of two West African coastal lagoons. Fisheries Management and Ecology 3:101-116.

Matsuda, H., and P. A. Abrams. 2006. Maximal yields from multispecies fisheries systems: rules for systems with multiple trophic levels. Ecological Applications 16:225-237.

McClanahan, T. R. 1995. A coral reef ecosystem-fisheries model: impacts of fishing intensity and catch selection on reef structure and processes. Ecological Modelling 80:1-19.

McClanahan, T. R. 2006. Challenges and accomplishments towards sustainable reef fisheries. Pages $147-182$ in I. M. Cote and J. D. Reynolds, editors. Coral reef conservation. Cambridge University Press, Cambridge, UK.

McClanahan, T. R. 2007. Management of area and gear in Kenyan coral reefs. Pages 166-185 in T. R. McClanahan and J. C. Castilla, editors. Fisheries management: progress towards sustainability. Blackwell Press, London, UK.

McClanahan, T. R., H. Glaesel, J. Rubens, and R. Kiambo. 1997. The effects of traditional fisheries management on fisheries yields and the coral-reef ecosystems of southern Kenya. Environmental Conservation 24:105-120.

McClanahan, T. R., N. A. J. Graham, J. M. Calnan, and M. A. MacNeil. 2007. Towards pristine biomass: reef fish recovery in coral reef marine protected areas in Kenya. Ecological Applications 17:1055-1067.

McClanahan, T. R., J. Maina, and J. Davies. 2005. Perceptions of resource users and managers towards fisheries management options in Kenyan coral reefs. Fisheries Management and Ecology 12:105-112.

McClanahan, T. R., J. Maina, and L. Pet-Soede. 2002. Effects of the 1998 coral mortality event on Kenyan coral reefs and fisheries. Ambio 31:543-550.

McClanahan, T. R., and S. Mangi. 2000. Spillover of exploitable fishes from a marine park and its effect on the adjacent fishery. Ecological Applications 10:1792-1805.

McClanahan, T. R., and S. Mangi. 2001. The effect of closed area and beach seine exclusion on coral reef fish catches. Fisheries Management and Ecology 8:107-121.

McClanahan, T. R., and S. Mangi. 2004. Gear-based management of a tropical artisanal fishery based on species selectivity and capture size. Fisheries Management and Ecology 11:5160 .

McClanahan, T. R., E. Verheij, and J. Maina. 2006. Comparing management effectiveness of a marine park and a multipleuse collaborative fisheries management area in East Africa. Aquatic Conservation: Marine and Freshwater Ecosystems $16: 147-165$.

McGoodwin, J. R. 1990. Crisis in the world's fisheries: people, problems, and policies. Stanford University Press, Stanford, California, USA.
McManus, J. W. 1996. Social and economic aspects of reef fisheries and their management. Pages 249-281 in N. V. C. Polunin and C. M. Roberts, editors. Reef fisheries. Chapman and Hall, London, UK.

McManus, J. W. 1997. Tropical marine fisheries and the future of coral reefs: a brief review with emphasis on Southeast Asia. Coral Reefs 16:S121-S127.

McManus, J. W., L. A. B. Menez, K. N. Kesner-Reyes, S. G. Vergara, and M. C. Ablan. 2000. Coral reef fishing and coralalgal phase shifts: implications for global reef status. Journal of Marine Science 57:572-578.

Micheli, F., P. Amarasekare, J. Bascompte, and L. R. Gerber. 2004. Including species interactions in the design and evaluation of marine reserves: some insights from a predator-prey model. Bulletin of Marine Science 74:653-669.

Newton, K., I. M. Cote, G. M. Pilling, S. Jennings, and N. K. Dulvy. 2007. Current and future sustainability of island coral reef fisheries. Current Biology 17:655-658.

Nixon, S. W. 1982. Nutrient dynamics, primary production and fisheries yields of lagoons. Pages 357-371 in Proceedings of the International Symposium on Coastal Lagoons (Bordeaux, France, 8-14 September 1981). Oceanologica Acta.

Pauly, D., M. L. Palomares, R. Froese, P. Sa-a, M. Vakily, D. Preikshot, and S. Wallace. 2001. Fishing down Canadian aquatic food webs. Canadian Journal of Fisheries and Aquatic Sciences 58:1-12.

Pauly, D., G. Silvestre, and I. Smith. 1989. On development, fisheries and dynamite: a brief review of tropical fisheries management. Natural Resource Modeling 3:307-329.

Polunin, N. V. C., and C. M. Roberts, editors. 1996. Reef fisheries. First edition. Chapman and Hall, London, UK.

Quinn, T. J. I., R. Gagen, and J. Zheng. 1990. Threshold management policies for exploited populations. Canadian Journal of Fisheries and Aquatic Sciences 47:2016-2029.

Sibly, R. M., D. Barker, M. C. Denham, J. Hone, and M. Pagel. 2005. On the regulation of populations of mammals, birds, fish, and insects. Science 309:607-610.

Sladek Nowlis, J., and C. M. Roberts. 1999. Fisheries benefits and optimal design of marine reserves. Fishery Bulletin 97: 604-616.

ter Braak, C. J. F. 1986. Canonical correspondence analysis: a new eigenvector technnique for multivariate direct gradient analysis. Ecology 67:1167-1179.

Turner, R. A., A. Cakacaka, N. A. J. Graham, N. V. C. Polunin, M. S. Pratchett, S. M. Stead, and S. K. Wilson. 2007. Declining reliance on marine resources in remote South Pacific societies: ecological versus socio-economic drivers. Coral Reefs 26:997-1008.

Underwood, A. J. 1994. On beyond BACI: sampling designs that might reliably detect environmental disturbances. Ecological Applications 4:3-15.

Underwood, A. J. 1997. Experiments in ecology. Cambridge University Press, Cambridge, UK.

Valentine, J. F., and K. L. Heck, Jr. 2005. Perspective review of the impacts of overfishing on coral reef food web linkages. Coral Reefs 24:209-213.

Worm, B., et al. 2006. Impacts of biodiversity loss on ocean ecosystem services. Science 314:787-790.

\section{APPENDIX}

Species composition, trophic level, and functional group information of the six major fishery groups targeted by the Kenyan artisanal coral reef fishery (Ecological Archives A018-053-A1).

\section{SUPPLEMENT}

Raw catch data (Ecological Archives A018-053-S1). 